\title{
APRESENTAÇÃO
}

\section{A PSICOLOGIA AMBIENTAL NO CAMPO INTERDISCIPLINAR DE CONHECIMENTO}

\author{
Sheila Walbe Ornstein \\ Faculdade de Arquitetura e Urbanismo - USP
}

sta parte agrega um conjunto de artigos compreendendo descrições, aná-
lises e comentários formulados por psicólogos e arquitetos / urbanistas, à propósito das várias facetas e possibilidades de interdisciplinaridade - na concepção e nas intervenções arquitetônicas, urbanas e do design de objetos - sob a perspectiva da qualidade de vida sustentável, desenvolvidos sobre o tema da Psicologia no estudo das questões ambientais. Há várias décadas, as áreas do conhecimento arquitetura, urbanismo e psicologia ambiental buscam - no plano acadêmico principalmente - demonstrar as efetivas possibilidades da colaboração interdisciplinar inscrevendo a psicologia ambiental em um campo interdisciplinar do conhecimento.

Romice, com formação em Arquitetura, sugere que tanto a Psicologia Ambiental como a Arquitetura e o Urbanismo se desenvolvem no ambiente, sendo que a psicologia é capaz de entender o comportamento do indivíduo no ambiente, e já a arquitetura e o desenho urbano têm habilidade de moldar o ambiente construído para atender às necessidades destes indivíduos e obtêm mais credibilidade se atreladas a "lugares" específicos.

O psicólogo ambiental Uzzell questiona quais os papéis do método para se alcançar - num contexto holístico - a prática interdisciplinar da Psicologia Ambiental. Uzzell aborda, também as relações desbalanceadas e, às vezes, conflituosas entre a Psicologia Ambiental e a Arquitetura, na medida 
em que a Psicologia Ambiental proporciona à Arquitetura muito mais teorias e alternativas metodológicas, não sendo a reciprocidade plenamente verdadeira. Mesmo assim, o autor considera essencial a busca da interdisciplinaridade pela Psicologia Ambiental em disciplinas como a Arquitetura, pois este caminho é que valida a pesquisa e a prática da primeira.

O psicólogo ambiental Moser tenta organizar, no plano conceitual, as possibilidades da colaboração multidisciplinar. Propõe três níveis (ou estágios) de colaboração: a monodisciplinaridade, a multidisciplinaridade, respectivamente no caso das atividades de pesquisa e de teoria e, de diagnósticos e auditorias e um terceiro nível de intervenções. Este último nível, no qual ocorreram proposições, soluções e suas implementações, tanto pode se dar no plano da interdisciplinaridade em que a Arquitetura e o desenho urbano e as Ciências Sociais caminham paralelamente para solução e implementação únicas ao final, como no plano da transdiciplinaridade, em que Arquitetura, desenho urbano e Ciências Sociais caminham de modo único, desde a definição do problema até a implementação das soluções. Ambas interdisciplinar e transdisciplinar - podem garantir a "validade ecológica" das proposições.

Estas ponderações, acrescidas por aquelas proferidas por Günther e Díaz, dão a medida da complexidade da atuação do arquiteto e do urbanista (ou desenhista urbano) e do psicólogo, se há intenção de se explorar as amplas possibilidades, no caso, das análises e das proposições comuns voltadas à maximização das relações ambiente construído - habitante, com ênfase na sustentabilidade. 